\title{
Supplementation of soft drinks with metallic ions reduces dissolution of bovine enamel
}

\author{
Heloisa Aparecida Barbosa da Silva PEREIRA ${ }^{1}$, Aline de Lima LEITE¹, Flávia de Moraes ITALIANI², Melissa Thiemi \\ $\mathrm{KATO}^{3}$, Juliano Pelim PESSAN ${ }^{4}$, Marília Afonso Rabelo BUZALAF ${ }^{5}$
}

\begin{abstract}
1- MSc, Department of Biological Sciences, Bauru School of Dentistry, University of São Paulo, Bauru, SP, Brazil.
2- DDS, Department of Biological Sciences, Bauru School of Dentistry, University of São Paulo, Bauru, SP, Brazil.

3- DDS, MSc, PhD, Department of Biological Sciences, Bauru School of Dentistry, University of São Paulo, Bauru, SP, Brazil.

4- DDS, MSc, PhD, Assistant Professor, Department of Pediatric Dentistry and Public Health, Araçatuba Dental School, Univ. Estadual Paulista - UNESP, SP, Brazil.

5- DDS, MSc, PhD, Chair Professor, Department of Biological Sciences, Bauru School of Dentistry, University of São Paulo, Bauru, SP, Brazil.
\end{abstract}

Corresponding address: Marília Afonso Rabelo Buzalaf - Departamento de Ciências Biológicas - Faculdade de Odontologia de Bauru - Universidade de São Paulo - Al. Octávio Pinheiro Brisolla, 9-75 - Bauru - SP - 17012-901 - Brasil - Phone: + 551432358246 - Fax: + 551432271486 - e-mail: mbuzalaf@fob.usp.br

Submitted: January 23, 2013 - Modification: May 14, 2013 - Accepted: June 20, 2013

\section{ABSTRACT}

\begin{abstract}
bjective: The aim of this study was to evaluate the effect of the addition of metallic ions to carbonated drinks on their erosive potential. Material and Methods: Powdered enamel was added to carbonated beverages (Coca-Cola ${ }^{\mathrm{TM}}$ or Sprite Zero ${ }^{\mathrm{TM}}$ ) and shaken for $30 \mathrm{~s}$. The samples were then immediately centrifuged and the supernatant removed. This procedure was repeated 5 times with the beverages containing $\mathrm{Cu}^{2+}, \mathrm{Mg}^{2+}, \mathrm{Mn}^{2+}$ or $\mathrm{Zn}^{2+}$ $(1.25-60 \mathrm{mmol} / \mathrm{L})$. For Coca-Cola ${ }^{\mathrm{TM}}$, the concentration of each ion that exhibited the highest protection was also evaluated in combination with $\mathrm{Fe}^{2+}$. The phosphate or calcium released were analyzed spectrophotometrically. Data were analyzed using ANOVA and Tukey's test $(p<0.05)$. Results: For Coca-Cola ${ }^{\mathrm{TM}}$, the best protective effect was observed for $\mathrm{Zn}^{2+}$ alone $(10 \mathrm{mmol} / \mathrm{L})$ or in combination $(1 \mathrm{mmol} / \mathrm{L})$ with other ions $(12 \%$ and $27 \%$, respectively, when compared with the control). Regarding Sprite Zero ${ }^{\mathrm{TM}}$, the best protective effect was observed for $\mathrm{Cu}^{2+}$ at 15 and $30 \mathrm{mmol} / \mathrm{L}$, which decreased the dissolution by $22-23 \%$. $\mathrm{Zn}^{2+}$ at $2.5 \mathrm{mmol} / \mathrm{L}$ also reduced the dissolution of powdered enamel by $8 \%$. Conclusions: The results suggest that the combination of metallic ions can be an alternative to reduce the erosive potential of Coca-Cola ${ }^{\mathrm{TM}}$. Regarding Sprite $\mathrm{Zero}^{\mathrm{TM}}$, the addition of $\mathrm{Cu}^{2+}$ seems to be the best alternative.
\end{abstract}

Key words: Tooth erosion. Carbonated beverages. Zinc. Copper. Manganese. Magnesium.

\section{INTRODUCTION}

Dental erosion is defined as loss of tooth substance by chemical processes, not involving bacteria, caused by a variety of intrinsic and extrinsic factors. Intrinsic factors are the result of endogenous acid, generally gastric acids that contact teeth especially in patients suffering from anorexia, bulimia and gastrointestinal disturbances ${ }^{21}$. Extrinsic factors are related to frequent consumption of acidic foodstuffs or beverages and exposure to acidic contaminants in the working environment ${ }^{29}$.

The consumption of citric fruit and juices, and industrialized beverages, especially soft drinks, has significantly increased during recent years, and has been associated with an increase in the prevalence of dental erosion ${ }^{9}$. Thus, the modification of the formula of acid beverages is one of the possible methods of minimizing their erosive effect. Some studies have demonstrated that fluoride is able to decrease the mineral loss of enamel and dentine under conditions of erosion ${ }^{16,28}$, but according to Larsen $^{13}$ (2001) acid beverages are able to dissolve the added fluoride, thus reducing its protective effect.

Therefore, some investigators have been focusing on the addition of other ions to acidic beverages. Among metallic ions, copper and iron seem to be plausible alternatives. Brookes, et al. ${ }^{3}$ (2003) developed a simple abiotic model to test the effects of copper ions on the inhibition of enamel demineralization. Using powdered enamel, these authors found that $10 \mathrm{mmol} / \mathrm{L} \mathrm{CuSO}_{4} \cdot 5 \mathrm{H}_{2} \mathrm{O}$ inhibited mineral loss by $49 \%$. The same authors found that 
$10 \mathrm{mmol} / \mathrm{L} \mathrm{FeSO}_{4} 7 \mathrm{H}_{2} \mathrm{O}$ inhibited mineral loss by $51 \%{ }^{2}$. Buzalaf, et al. ${ }^{4}$ (2006) used the same model to determine the potential of $\mathrm{FeSO}_{4} \cdot 7 \mathrm{H}_{2} \mathrm{O}$ to inhibit the demineralization of bovine enamel powder. The concentration of $15 \mathrm{mmol} / \mathrm{L}$ reduced the dissolution of enamel powder by $50 \%$. Kato, et al. ${ }^{11,12}$ (2007) studied the addition of iron (10 mmol/L FeSO $\left.\mathrm{m}_{4}\right)$ to carbonated drinks and concluded that this ion can reduce bovine tooth erosion provoked by acid drinks, but this effect is dependent on the type of acid presented in the drink.

The structure and composition of hydroxyapatite can be altered, since calcium can be replaced by other cations, such as metallic ions presenting similar physical and chemical properties ${ }^{18}$. Among them, manganese is essential for humans, playing a role in bone mineralization. It is an important constituent of cartilage and connective tissue $\mathrm{e}^{5,19,24}$. Zinc is an essential oligoelement, environmentally ubiquitous and essential for life, important for the synthesis of proteins and nucleic acids, for normal growth of the body and for the duplication of the tissues ${ }^{18,25}$. Copper is an essential trace element and constitutes a vital part of several enzymes (e.g., ferroxidases, cytochrome c oxidase, superoxide dismutase, tyrosinase, lysyl oxidase, and dopamine beta hydroxylase). It is also involved in protein and energy metabolism, metabolic regulation, cellular protection from damaging caused by free radical species, and the formation of glycosaminoglycans ${ }^{18,19}$. Magnesium is an essential element and has an important role as a co-factor in more than 300 enzymatic reactions involving energy metabolism ${ }^{15}$. Thus, these metallic ions could be candidates for participation in the process of de- and remineralization under conditions of erosive challenges.

Based on the above-mentioned studies, it would be worth evaluating the effect of the addition of other metallic ions to carbonated drinks, such as zinc, manganese, magnesium and copper with the aim of assessing their potential to reduce the dissolution of bovine enamel powder, as has been observed for copper and iron. Their effect was also assessed when combined with iron, since this metal has been reported to reduce the loss of enamel and dentin under erosive challenges caused by soft drinks ${ }^{10,20}$.

\section{MATERIAL AND METHODS}

\section{Bovine enamel powder preparation}

Fragments of permanent bovine enamel were obtained from bovine incisors. The teeth were sterilized by storage in $10 \%$ formalin buffered solution, $\mathrm{pH} 7$, for 30 days. Using one diamond disk (Isomet 1000; Buehler, Lake Bluff, IL, USA) the crowns were sectioned from the roots. Next, using three parallel diamond disks, separated by two $4 \mathrm{~mm}$ spacers, 8-10 fragments were cut from the crown of each bovine incisor. About one hundred enamel slabs ( $4 \mathrm{~mm} \times 4 \mathrm{~mm}$ ) were obtained and these fragments had their dentine totally removed by abrasion with 320 grit $\mathrm{Al}_{2} \mathrm{O}_{3}$ papers (Buehler, Buehler, Lake Bluff, Ilinois, USA) coupled to a polishing machine (APL-4/AROTEC, AROTEC, Cotia, $\mathrm{SP}$, Brazil). The complete removal of dentine was checked microscopically (40x magnification).

Enamel was then ground to a very fine powder with a ball mill (KM1 model MLW, Hergerstellt, Wittenberg, Saxony-Anhalt, Germany). From the enamel powder, particles between 75 and $106 \mu \mathrm{m}$ were selected using appropriated meshes (Bertel, Comercial Elétrica Ltda, Caieiras, SP, Brazil).

\section{Treatment}

At time zero, $0.4 \mathrm{~mL}$ of carbonated beverages (Coca-Cola $^{\mathrm{m}}$ or Sprite Zero ${ }^{\mathrm{m}}$, Cia. de Bebidas Ipiranga, Ribeirão Preto, SP, Brazil) were added to $40 \mathrm{mg}$ of powdered bovine enamel (1 $\mathrm{mg}$ enamel powder/10 $\mu \mathrm{L}$ beverage) and shaken for $30 \mathrm{~s}$. The sample was immediately centrifuged for $30 \mathrm{~s}(11,000 \mathrm{rpm})$ and the supernatant was removed at 1 min $40 \mathrm{~s}$ after centrifugation ${ }^{3,11}$. This procedure was repeated with the carbonated beverages containing different concentrations $(1.25,2.5,5,10,15,30$ and $60 \mathrm{mmol} / \mathrm{L})$ of $\mathrm{MnSO}_{4}$. $\mathrm{H}_{2} \mathrm{O}, \mathrm{MgSO}_{4} .7 \mathrm{H}_{2} \mathrm{O}, \mathrm{CuSO}_{4} .5 \mathrm{H}_{2} \mathrm{O}$ or $\mathrm{ZnSO}_{4} .7 \mathrm{H}_{2} \mathrm{O}$ (Merck, Merck KGaA, Darmstadt, Hesse, Germany). Additionally, for Coca-Cola ${ }^{m}$ only, the effect of the combination of different ions, including iron, was also tested. This was done only for Coca-Cola ${ }^{T M}$ in order to see if the combination of different ions at lower concentrations could protect against enamel dissolution. For this purpose, the concentration of each ion that presented the best protective effect was added to the soft drink $\left(\mathrm{ZnSO}_{4} .7 \mathrm{H}_{2} \mathrm{O}, \mathrm{MnSO}_{4}\right.$. $\mathrm{H}_{2} \mathrm{O}, \mathrm{CuSO}_{4} .5 \mathrm{H}_{2} \mathrm{O}$ and $\mathrm{FeSO}_{4} \cdot 7 \mathrm{H}_{2} \mathrm{O}$ in concentrations of $10 \mathrm{mmol} / \mathrm{L})$. The concentration of $1 \mathrm{mmol} / \mathrm{L}$ was also evaluated in order to observe if the same effect could be obtained with a dose that could be more viable considering taste alterations and possible toxic effects.

Thus, we had 8 experiments conducted with each isolated compound $\left(\mathrm{MnSO}_{4} \cdot \mathrm{H}_{2} \mathrm{O}, \mathrm{MgSO}_{4} .7 \mathrm{H}_{2} \mathrm{O}\right.$, $\mathrm{CuSO}_{4} .5 \mathrm{H}_{2} \mathrm{O}$ or $\mathrm{ZnSO}_{4} .7 \mathrm{H}_{2} \mathrm{O}$ ) for each soft drink tested (Coca-Cola ${ }^{T m}$ or Sprite Zero ${ }^{T m}$ ). Two additional experiments were conducted with Coca-Cola ${ }^{\mathrm{m}}$ only for testing the effect of the combination of different ions, including iron (all ions at 1 or $10 \mathrm{mmol} / \mathrm{L}$ ).

\section{Phosphate determination}

In order to determine the amount of dissolved enamel powder, phosphate released in the supernatant was analyzed colorimetrically, in triplicate, using the Fiske-Subarrow method ${ }^{6}$ (Cary 
50, Pharmacia Biotech, Cambridge, Cambridgeshire, England). Samples were read against standard phosphate solutions containing $0.75,1.5,3.0,6.0$, 12.0 and $24 \mathrm{mg} P$. The absorbance readings were converted to $\mathrm{mg}$ phosphate using a standard curve with a coefficient correlation of $r \geq 0.99$.

\section{Calcium determination}

Calcium concentrations were determined colorimetrically in duplicate at $650 \mathrm{~nm}$ (Cary 50, Pharmacia Biotech, Cambridge, Cambridgeshire, England). Preparation of the samples for measuring calcium concentration was conducted by the Arsenazo III method, previously described by Smith and Bauer ${ }^{23}$ (1979) (Arsenazo III reacts with calcium in a solution to form a bluish-purple complex. The intensity of the resulting color is proportional to the calcium concentration and can be determined spectrophotometrically according to the Beer-Lambert law). Concentrations in reagent R1 (Biocon, Biocon Diagnostik, Vöhl/Marienhagen, Hesse, Germany), which is a buffered color reagent, were as follows: $100 \mathrm{mmol} / \mathrm{L}$ imidazole buffer $(\mathrm{pH}$ 6.5) and $0.12 \mathrm{mmol} / \mathrm{L}$ Arsenazo III. The standard was prepared from $\mathrm{CaCl}_{2}$ and the solvent used was the beverage at $200 \mu \mathrm{g} / \mathrm{mL}$ calcium. The standard reagent was diluted with the beverage (Coca-Cola ${ }^{\mathrm{TM}}$ or Sprite Zero $^{\mathrm{Tm}}$ ) resulting in the following calcium concentrations: $1.25,2.5,5$ and $10 \mu \mathrm{g} / \mathrm{mL}$ Ca. With the intention of obtaining a safe edge in the reading, samples were diluted in the ratio of $1: 1$ $(\mathrm{v}: \mathrm{v})$. For the preparation of the blank, soft drink was used instead of water so that the calcium originally present in the water would not interfere in the results.
Statistical analysis

The assumptions of equality of variances and normal distribution of errors were checked. Since the assumptions were satisfied, one-way ANOVA was chosen. For individual comparisons among the different concentrations of metallic ions in respect to control group (no metal), Tukey's test was used. The significance level was set at $5 \%$.

\section{RESULTS}

\section{Phosphate determination}

The amount of phosphate released was normalized for the value of one (100\%) representing the phosphate released from control samples (no metallic ions added, only beverage). Tables 1 and 2 show the mean amount of phosphate released and the normalized data of powdered enamel dissolved in function of increasing concentrations of the ions added to Coca-Cola ${ }^{\mathrm{T}}$ and to Sprite Zero $^{T M}$, respectively. The addition of $\mathrm{Mn}^{2+}, \mathrm{Mg}^{2+}$ or $\mathrm{Cu}^{2+}$ to Coca-Cola ${ }^{\text {Tm}}$ (Table 1) did not significantly alter the enamel dissolution in relation to the control $(p>0.05)$. Regarding the addition of $\mathrm{Zn}^{2+}$ to Coca-Cola ${ }^{\mathrm{m}}$, at concentrations above $10 \mathrm{mmol} / \mathrm{L}$, there was a significant reduction in the dissolution of powdered bovine enamel in relation to the control $(12 \%, 10 \%, 13 \%$ and $20 \%$, respectively for concentrations of $10,15,30$ and $60 \mathrm{mmol} / \mathrm{L}$, $\mathrm{p}<0.05$ ).

For Sprite Zero $^{\text {Tm }}$ (Table 2) the addition of $\mathrm{Mn}^{2+}$ did not significantly alter the enamel dissolution in relation to the control ( $p>0.05)$. The addition of $\mathrm{Mg}^{2+}$ at 30 and $60 \mathrm{mmol} / \mathrm{L}$ to Sprite Zero ${ }^{\mathrm{m}}$ significantly increased the dissolution of the powdered enamel $(p<0.01)$, while $\mathrm{Zn}^{2+}$ at $2.5 \mathrm{mmol} / \mathrm{L}$ significantly reduced enamel dissolution in respect to control

Table 1- Mean ( $(\mathrm{SD})$ amount of phosphate released and normalized data of powdered enamel dissolved in function of increasing ion concentrations added to Coca-Cola ${ }^{\mathrm{TM}}$

\begin{tabular}{|c|c|c|c|c|c|c|c|c|}
\hline \multirow{2}{*}{$\begin{array}{c}\text { Concentration } \\
(\mathrm{mmol} / \mathrm{L})\end{array}$} & \multicolumn{2}{|c|}{ Copper } & \multicolumn{2}{|c|}{ Zinc } & \multicolumn{2}{|c|}{ Magnesium } & \multicolumn{2}{|c|}{ Manganese } \\
\hline & $\begin{array}{l}\text { Amount of } \\
\text { phosphate } \\
\text { released } \\
(\mathrm{mg})\end{array}$ & $\begin{array}{c}\text { Normalised } \\
\text { data }\end{array}$ & $\begin{array}{l}\text { Amount of } \\
\text { phosphate } \\
\text { released } \\
(\mathrm{mg})\end{array}$ & $\begin{array}{c}\text { Normalised } \\
\text { data }\end{array}$ & $\begin{array}{l}\text { Amount of } \\
\text { phosphate } \\
\text { released } \\
(\mathrm{mg})\end{array}$ & $\begin{array}{c}\text { Normalised } \\
\text { data }\end{array}$ & $\begin{array}{l}\text { Amount of } \\
\text { phosphate } \\
\text { released } \\
(\mathrm{mg})\end{array}$ & $\begin{array}{c}\text { Normalised } \\
\text { data }\end{array}$ \\
\hline 0 & $21.28 \pm 1.15$ & 1.00 & $21.28 \pm 1.15$ & 1.00 & $22.60 \pm 0.74$ & 1.00 & $21.5 \pm 1.52$ & 1.00 \\
\hline 1.25 & $23.43 \pm 0.83$ & $1.10 \pm 0.04$ & $22.19 \pm 0.80$ & $1.04 \pm 0.04$ & $21.99 \pm 0.86$ & $0.97 \pm 0.04$ & $20.95 \pm 2.78$ & $0.97 \pm 0.10$ \\
\hline 2.5 & $21.85 \pm 0.76$ & $1.03 \pm 0.04$ & $21.44 \pm 1.78$ & $1.01 \pm 0.08$ & $21.79 \pm 1.53$ & $0.96 \pm 0.06$ & $22.20 \pm 2.21$ & $1.04 \pm 0.12$ \\
\hline 5 & $21.17 \pm 0.93$ & $1.06 \pm 0.14$ & $20.04 \pm 1.06$ & $0.94 \pm 0.05$ & $22.56 \pm 0.67$ & $1.00 \pm 0.04$ & $20.76 \pm 1.21$ & $0.97 \pm 0.04$ \\
\hline 10 & $20.38 \pm 0.41$ & $0.96 \pm 0.02$ & $18.74 \pm 0.89$ & $0.88 \pm 0.04^{*}$ & $22.37 \pm 0.24$ & $1.00 \pm 0.04$ & $20.27 \pm 0.99$ & $0.95 \pm 0.04$ \\
\hline 15 & $20.41 \pm 0.42$ & $0.96 \pm 0.02$ & $19.22 \pm 0.92$ & $0.90 \pm 0.04^{*}$ & $22.25 \pm 1.16$ & $0.99 \pm 0.07$ & $19.90 \pm 0.88$ & $0.93 \pm 0.05$ \\
\hline 30 & $19.86 \pm 0.78$ & $0.93 \pm 0.04$ & $18.53 \pm 0.57$ & $0.87 \pm 0.03^{*}$ & $23.20 \pm 0.93$ & $1.03 \pm 0.05$ & $20.01 \pm 0.89$ & $0.93 \pm 0.03$ \\
\hline 60 & $19.82 \pm 0.75$ & $0.93 \pm 0.04$ & $16.95 \pm 0.95$ & $0.80 \pm 0.04^{*}$ & $23.87 \pm 0.77$ & $1.06 \pm 0.06$ & $19.91 \pm 0.99$ & $0.93 \pm 0.06$ \\
\hline
\end{tabular}

*Significantly different from control (ANOVA and Tukey's test, $p<0.05) n=5$ 
Table 2- Mean ( $\pm S D$ ) amount of phosphate released and normalized data of powdered enamel dissolved in function of increasing ion concentrations added to Sprite Zero ${ }^{\mathrm{TM}}$

\begin{tabular}{ccccccc}
\hline $\begin{array}{c}\text { Concentration } \\
\text { mmol/L }\end{array}$ & \multicolumn{2}{c}{ Zinc } & \multicolumn{2}{c}{ Magnesium } & \multicolumn{2}{c}{ Manganese } \\
\hline & $\begin{array}{c}\text { Amount of } \\
\text { phosphate } \\
\text { released } \\
(\mathrm{mg})\end{array}$ & $\begin{array}{c}\text { Normalised } \\
\text { data }\end{array}$ & $\begin{array}{c}\text { Amount of } \\
\text { phosphate } \\
\text { released } \\
(\mathrm{mg})\end{array}$ & $\begin{array}{c}\text { Normalised } \\
\text { data }\end{array}$ & $\begin{array}{c}\text { Amount of } \\
\text { phosphate } \\
\text { released } \\
(\mathrm{mg})\end{array}$ & $\begin{array}{c}\text { Normalised } \\
\text { data }\end{array}$ \\
\hline 0 & $27.47+0.64$ & 1.00 & $27.27+0.98$ & 1.00 & $27.20+1.57$ & 1.00 \\
1.25 & $26.08+0.64$ & $0.95+0.01$ & $28.99+1.43$ & $1.06+0.08$ & $25.77+4.4$ & $0.95+0.12$ \\
2.5 & $25.36+0.56$ & $0.92+0.01^{*}$ & $29.66+1.68$ & $1.09+0.06$ & $28.54+1.52$ & $0.98+0.09$ \\
5 & $25.98+0.51$ & $0.95+0.02$ & $28.41+3.57$ & $1.04+0.13$ & $28.82+0.78$ & $1.06+0.06$ \\
10 & $26.87+0.62$ & $0.98+0.02$ & $29.99+1.49$ & $1.10+0.07$ & $26.40+1.86$ & $0.98+0.12$ \\
15 & $26.02+2.25$ & $0.95+0.08$ & $31.35+1.17$ & $1.15+0.06$ & $29.20+0.32$ & $1.08+0.05$ \\
30 & $28.16+0.60$ & $1.03+0.03$ & $32.55+1.79$ & $1.20+0.11^{*}$ & $28.88+1.50$ & $1.07+0.09$ \\
\hline 60 & $29.04+0.77$ & $1.06+0.02$ & $36.12+1.36$ & $1.33+0.05^{*}$ & $27.75+3.60$ & $1.01+0.12$ \\
\hline
\end{tabular}

*Significantly different from control (ANOVA and Tukey's test, $p<0.05) n=5$

Table 3- Mean (SD) amount of calcium $(\mu \mathrm{g})$ released and normalized data of powdered enamel dissolved in function of increasing ion concentrations added to Sprite Zero $^{\mathrm{TM}}$

\begin{tabular}{ccc}
\hline $\begin{array}{c}{[\mathrm{Cu}]} \\
(\mathrm{mmol} / \mathrm{L})\end{array}$ & $\begin{array}{c}\text { Amount of calcium } \\
\text { released }\end{array}$ & Normalized data \\
\hline 0 & $8.86 \pm 0.65$ & $1.00 \pm 0.09$ \\
1.25 & $8.04 \pm 0.88$ & $0.91 \pm 0.08$ \\
2.5 & $7.72 \pm 0.48$ & $0.87 \pm 0.10$ \\
5 & $7.74 \pm 0.59$ & $0.88 \pm 0.05$ \\
10 & $7.69 \pm 0.13$ & $0.87 \pm 0.06$ \\
15 & $6.83 \pm 0.15$ & $0.77 \pm 0.05^{*}$ \\
30 & $6.93 \pm 0.34$ & $0.78 \pm 0.07^{*}$ \\
60 & $9.26 \pm 0.32$ & $1.05 \pm 0.01$ \\
\hline
\end{tabular}

*Significantly different from control (ANOVA and Tukey's test, $\mathrm{p}<0.05) . \mathrm{n}=5$

Table 4- Mean $( \pm S D)$ amount of calcium $(\mu \mathrm{g})$ released and normalized data of powdered enamel dissolved in function of increasing ion concentrations added to CocaCola $^{\mathrm{TM}}$

\begin{tabular}{ccc}
\hline $\begin{array}{c}\text { [Fe], [Cu], [Zn] } \\
\text { and [Mn] } \\
\text { (mmol/L) }\end{array}$ & $\begin{array}{c}\text { Amount } \\
\text { of calcium } \\
\text { released }\end{array}$ & Normalised data \\
\hline 0 & $2.74 \pm 0.09$ & 1.00 \\
1 & $1.99 \pm 0.09$ & $0.73 \pm 0.03^{*}$ \\
10 & $5.90 \pm 0.25$ & $2.15 \pm 0.09^{*}$ \\
\hline
\end{tabular}

*Significantly different from control (ANOVA and Tukey's test, $\mathrm{p}<0.05) \mathrm{n}=5$ $(p<0.05)$. For the other conditions, the differences were not significant $(p>0.05)$.

\section{Calcium determination}

As with phosphate, the amount of calcium released was normalized for the value of 1 $(100 \%)$, representing the calcium present in the control samples (no metallic ions added). Table 3 presents the mean amount of calcium normalized from the enamel powder dissolved in increasing concentrations of $\mathrm{Cu}^{2+}$ added to Sprite Zero ${ }^{\mathrm{T}}$. Only concentrations of 15 and $30 \mathrm{mmol} / \mathrm{L}$ significantly reduced enamel dissolution when compared to the control.

Table 4 shows the results of the simultaneous addition of $\mathrm{Fe}^{2+}, \mathrm{Cu}^{2+}, \mathrm{Mn}^{2+}$ and $\mathrm{Zn}^{2+}$ at concentrations of 1.0 or $10 \mathrm{mmol} / \mathrm{L}$ to Coca-Cola ${ }^{\mathrm{Tm}}$. For the concentration of $1 \mathrm{mmol} / \mathrm{L}$, a significant reduction in dissolution in relation to the control (27\%) was observed. For the concentration of $10 \mathrm{mmol} / \mathrm{L}$, however, there was a significant increase in enamel dissolution (115\%).

\section{DISCUSSION}

Among the strategies for minimizing the erosive process of dental structures, the modification of beverages is one of the most studied ones recently. Such modifications include the addition of ions to erosive beverages, including metallic ions, which was the aim of the present study. It should be noted that Sprite Zero ${ }^{T m}$ supplemented with copper presented a bluish color that interfered in the Fiske-Subarrow reaction. For this reason, enamel dissolution in this case was estimated through calcium assay using the arsenazo III method. When 
copper was added to Sprite Zero ${ }^{T m}$, there was a significant reduction in enamel dissolution (Table 3). Such a finding is of interest, since this is the first study demonstrating the protective effect of this ion against enamel dissolution caused by Sprite Zero $^{\text {Tm }}$. Brookes, et al. ${ }^{3}$ (2003) also obtained positive results when they added $\mathrm{Cu}^{2+}$, at $10 \mathrm{mmol} / \mathrm{L}$, to acetic acid, which significantly reduced the degree of dissolution of the enamel, reaching maximum inhibition (around 50\%) in the concentration of 5 $\mathrm{mmol} / \mathrm{L}$. However, this behavior was not observed when copper was added to Coca-Cola ${ }^{\mathrm{Tm}}$, probably due to the different type of acid presented in this beverage (phosphoric acid). These data are similar to those previously described by Buzalaf, et al. ${ }^{4}$ (2006) and Kato, et al.11 (2007) for $\mathrm{Fe}^{2+}$. In the study by Buzalaf, et al. ${ }^{4}$ (2006), when $\mathrm{Fe}^{2+}$ at 15 $\mathrm{mmol} / \mathrm{L}$ was added to acetic acid, it inhibited the dissolution of the enamel powder around 50\%. However, when $\mathrm{Fe}^{2+}$ was added to Coca-Cola ${ }^{\mathrm{Tm}}$, the maximum inhibition (around $17 \%$ ) was reached only at the concentration of $60 \mathrm{mmol} / \mathrm{L}^{12}$.

With respect to zinc, a positive result occurred when it was added to Coca-Cola ${ }^{\mathrm{T}}$, thereby suggesting that it could be used as a possible strategy to reduce the erosive potential of this soft drink. However, its action was significant only at $10 \mathrm{mmol} / \mathrm{L}$ (around $70 \mathrm{mg} / \mathrm{L}$ ), which is a high concentration for human consumption. A human adult requirement of zinc is $15-22 \mathrm{mg} / \mathrm{day}$, according to the World Health Organization ( $\mathrm{WHO}^{27}$ ) (2003). Therefore, its use requires caution and needs to be further investigated.

For $\mathrm{Mn}^{2+}, \mathrm{Cu}^{2+}$ and $\mathrm{Mg}^{2+}$, significant differences were not observed when added to Coca-Cola ${ }^{\mathrm{Tm}}$ in relation to the control, despite $\mathrm{Mn}^{2+}$ having a better action when compared to $\mathrm{Mg}^{+2}$. The fact that high concentrations of $\mathrm{Zn}^{2+}, \mathrm{Mn}^{2+}, \mathrm{Cu}^{2+}$ and $\mathrm{Mg}^{2+}$ added to Sprite $Z^{2}{ }^{\mathrm{Tm}}$ led to an inverse effect (increase in the degree of dissolution of the enamel powder) could possibly be due to chelation in the presence of citric acid in Sprite Zero ${ }^{\mathrm{TM}}$. Attin, et al. ${ }^{1}$ (2004) showed that citric acid is able to form a chelation complex with $\mathrm{Ca}^{2+}$, leading to a drop in $\mathrm{pH}$, due to the release of $\mathrm{H}^{+}$, according to the following equation: $2 \mathrm{CitH}_{3}+\mathrm{Ca}^{2+}=\left(\mathrm{CaCit}_{2}\right)^{4-}+6 \mathrm{H}^{+}$. In the study by Kato, et al. ${ }^{11}(2007)$, it was also observed that the presence of $\mathrm{Fe}^{2+}$ in high concentrations caused an increase in the degree of dissolution of Sprite Zero ${ }^{\mathrm{T}}$, which could possibly be attributed to this chelation effect. This appears to be the case for $\mathrm{Zn}^{2+}, \mathrm{Mn}^{2+}$, $\mathrm{Cu}^{2+}$ and $\mathrm{Mg}^{2+}$ in the present study.

The different erosive potentials of distinct soft drinks have been shown in many studies that have evaluated the effects of these drinks on dental substrates $8,17,22,26$. In general, all soft drinks present a low $\mathrm{pH}$ and their erosive potential is not only due to $\mathrm{pH}$. There is also a strong association with the chelant properties of the acid in respect to calcium, which is more evident for citric acid7,14,29.

The simultaneous addition of $\mathrm{Fe}^{2+}, \mathrm{Cu}^{2+}, \mathrm{Zn}^{2+}$ and $\mathrm{Mn}^{2+}$ ions to Coca-Cola ${ }^{\mathrm{rm}}$ led to an increase in enamel dissolution by the combination of ions at high concentration $(10 \mathrm{mmol} / \mathrm{L})$. There is no apparent explanation for this, but interestingly, inhibition of dissolution occurred with the lowest dose tested ( $1 \mathrm{mmol} / \mathrm{L})$, indicating an inverted dose-response behavior. It would be interesting to study the addition of lower concentrations of ions, which could increase the inhibitory effect. Additionally, this would be a more viable strategy because it would cause less alteration of the beverage's flavor and would cause less concern, from the toxicological point of view. Based on the results obtained in the present study, it seems that different strategies can be adopted for the reduction of the erosive potential of different soft drinks. Among the strategies evaluated, the addition of $\mathrm{Cu}^{2+}$ to Sprite Zero $^{\mathrm{Tm}}$ at concentrations of 15 or $30 \mathrm{mmol} / \mathrm{L}$ seems to be the best alternative, according to the experimental model of the present study. It would be interesting to investigate whether the simultaneous addition of $\mathrm{Cu}^{2+}$ plus other metals could increase the inhibitory effect of enamel dissolution, as this might allow the use of lower doses of metals. Regarding Coca-Cola ${ }^{\mathrm{Tm}}$, the best strategy was the combination of $\mathrm{Fe}^{2+}, \mathrm{Zn}^{2+}$, $\mathrm{Cu}^{2+}$ and $\mathrm{Mn}^{2+}$ at $1 \mathrm{mmol} / \mathrm{L}$. In this case, the effect was dose-dependent, with inhibition occurring with the lower dose tested. It also would be interesting to study the addition of lower related concentrations of ions, which could increase their inhibitory effect. It is important to mention that the model employed in the present study used powdered enamel, which allows a higher surface area of contact with the soft drinks. It would be interesting to conduct similar in vitro and, as a further step, in situ studies using enamel blocks, which could mimic better what could be expected to occur in the clinical situation.

\section{CONCLUSION}

The results suggest that the combination of metallic ions can be an alternative to reduce the erosive potential of Coca-Cola ${ }^{\mathrm{TM}}$. Regarding Sprite Zero $^{T M}$, the addition of $\mathrm{Cu}^{2+}$ seems to be the best alternative. Finally, it is important to mention that the addition of metals to soft drinks must be done with care in order to avoid toxic effects.

\section{ACKNOWLEDGMENTS}

This investigation was supported by FAPESP - São Paulo Research Foundation (Grant n. 2007/04222-7). 


\section{REFERENCES}

1- Attin T, Buchalla W, Hannig C, Becker K. Dentine erosion by two citric acid concentrations with varying amounts of calcium. Caries Res. 2004;38:357.

2- Brookes SJ, Robinson C, Shore RC, Kirkham J. Inhibitory effect of metal ions on acid demineralisation. Caries Res. 2004;38:401. 3- Brookes SJ, Shore RC, Robinson C, Wood SR, Kirkham J. Copper ions inhibit the demineralisation of human enamel. Arch Oral Biol. 2003;48(1):25-30.

4- Buzalaf MA, Moraes Italiani F, Kato MT, Martinhon CC, Magalhães AC. Effect of iron on inhibition of acid demineralisation of bovine dental enamel in vitro. Arch Oral Biol. 2006;51(10):844-8.

5- Crossgrove J, Zheng W. Manganese toxicity upon overexposure. NMR Biomed. 2004;17(8):544-53.

6- Fiske HC. The colorimetric determination of phosphorus. Journal Biol Chem. 1925;66:375-400.

7- Gudmundsson K, Kristleifsson G, Theodors A, Holbrook WP. Tooth erosion, gastroesophageal reflux, and salivary buffer capacity. Oral Surg Oral Med Oral Pathol Oral Radiol Endod. $1995 ; 79(2): 185-9$.

8- Issa AI, Toumba KJ, Preston AJ, Duggal MS. Comparison of the effects of whole and juiced fruits and vegetables on enamel demineralisation in situ. Caries Res. 2011;45(5):448-52.

9- Järvinen VK, Rytömaa II, Heinonen OP. Risk factors in dental erosion. J Dent Res. 1991;70(6):942-7.

10- Kato MT, Buzalaf MA. Iron supplementation reduces the erosive potential of a cola drink on enamel and dentin in situ. J Appl Oral Sci. 2012;20(3):318-22.

11- Kato MT, Maria AG, Sales-Peres SH, Buzalaf MA. Effect of iron on the dissolution of bovine enamel powder in vitro by carbonated beverages. Arch Oral Biol. 2007;52(7):614-7.

12- Kato MT, Sales-Peres SH, Buzalaf MA. Effect of iron on acid demineralisation of bovine enamel blocks by a soft drink. Arch Oral Biol. 2007;52(11):1109-11.

13- Larsen MJ. Prevention by means of fluoride of enamel erosion as caused by soft drinks and orange juice. Caries Res. 2001;35(3):229-34.

14- Lussi A, Jäggi T, Schärer $S$. The influence of different factors on in vitro enamel erosion. Caries Res. 1993;27(5):387-93.
15- MacLeod D, MacLeod J. Magnesium: physiology and pharmacology. Br J Anaesth. 1999;83(2):302-20.

16- Magalhães AC, Wiegand A, Rios D, Buzalaf MA, Lussi A. Fluoride in dental erosion. Monogr Oral Sci. 2011;22:158-70.

17- Meurman JH, Frank RM. Progression and surface ultrastructure of in vitro caused erosive lesions in human and bovine enamel. Caries Res. 1991;25(2):81-7.

18- Nikolić R, Kaličanin B, Krstić N. The release of zinc, copper, lead, and cadmium from the mineral tissue of teeth under the influence of soft drinks and sour-tasting food. Connect Tissue Res. 2012;53(3):229-35.

19- Nordberg GF, Nordberg M. Handbook on the toxicology of metals. $3^{\text {rd }}$ ed. Amsterdam: Elsevier/Academic Press; 2007.

20- Sales-Peres SH, Pessan JP, Buzalaf MA. Effect of an iron mouthrinse on enamel and dentine erosion subjected or not to abrasion: an in situ/ex vivo study. Arch Oral Biol. 2007;52(2):12832.

21- Scheutzel P. Etiology of dental erosion - intrinsic factors. Eur J Oral Sci. 1996;104(2):178-90.

22- Smith AJ, Shaw L. Baby fruit juices and tooth erosion. Br Dent J. $1987 ; 162(2): 65-7$.

23- Smith HG Jr, Bauer PJ. Light-induced permeability changes in sonicated bovine disks: arsenazo III and flow system measurements. Biochemistry. 1979;18(23):5067-73.

24- Utter MF. The biochemistry of manganese. Med Clin North Am. 1976;60(4):713-27

25- Walsh CT, Sandstead HH, Prasad AS, Newberne PM, Fraker PJ. Zinc: health effects and research priorities for the 1990s. Environ Health Perspect. 1994;102(Suppl 2):5-46.

26- West NX, Hughes JA, Addy M. The effect of $\mathrm{pH}$ on the erosion of dentine and enamel by dietary acids in vitro. J Oral Rehabil. 2001;28(9):860-4.

27- World Health Organization. Guidelines for drinking-water quality. Geneva: WHO; 2003.

28- Yu H, Attin T, Wiegand A, Buchalla W. Effects of various fluoride solutions on enamel erosion in vitro. Caries Res. 2010;44(4):390401.

29- Zero DT. Etiology of dental erosion - extrinsic factors. Eur J Oral Sci. 1996;104(2):162-77. 